Max-Planck-Institut für demografische Forschung

Max Planck Institute for Demographic Research

Konrad-Zuse-Strasse $1 \cdot$ D-18057 Rostock · GERMANY

Tel +49 (0) 3812081 - 0; Fax +49 (0) 3812081 - 202;

http://www.demogr.mpg.de

MPIDR WORKING PAPER WP 2007-001

JANUARY 2007

First and second births in first

and second unions:

a decomposition of fertility decline

in Bulgaria and Russia since the

1989 economic and political transition

Martin Spielauer (spielauer@demogr.mpg.de)

Elena Koytcheva (koytcheva@demogr.mpg.de)

Dora Kostova (kostova@demogr.mpg.de)

This working paper has been approved for release by: Vladimir M. Shkolnikov (shkolnikov@demogr.mpg.de), Head of the Laboratory for Demographic Data.

(C) Copyright is held by the authors.

Working papers of the Max Planck Institute for Demographic Research receive only limited review. Views or opinions expressed in working papers are attributable to the authors and do not necessarily reflect those of the Institute. 


\title{
First and second births in first and second unions: a decomposition of fertility decline in Bulgaria and Russia since the 1989 economic and political transition
}

\author{
Martin Spielauer, Elena Koytcheva, Dora Kostova \\ December 2006
}

\begin{abstract}
Following the collapse of the communist regimes in Bulgaria and Russia, the two countries have experienced dramatic fertility decline. The aim of this paper is to examine the individual contribution of various factors that have contributed to the overall drop in first and second births. By means of microsimulation, we isolate the effect of changes observed in first and second birth risks in different life course situations as well as the impact of changes in union formation and dissolution on fertility. The study is based on hazard regression models estimated from GGS data. We find remarkable similarities in first and second birth behavior and changes in these behaviors over time in both countries. However, partnership behavior and trends differ considerably, causing a stronger fertility decline in Bulgaria due to delayed partnership formation. Nevertheless, in Russia unions are increasingly unstable, a process which, according to our findings, leads to longer birth intervals but has almost no impact on final birth outcome.
\end{abstract}

\section{Introduction}

Bulgaria and Russia experienced fast fertility decline after the collapse of communism, as did all countries of the former Soviet Bloc. At the starting point of the transition, we find almost identical demographic patterns in the two countries, characterized by very early and universal marriage, universal parenthood, and a strong two-child norm. Until 1989 period fertility was remarkably stable around replacement level. An international comparison of the distribution of family sizes of the 1960 female birth cohorts of 21 countries identified Bulgaria as the country with the lowest inter-individual diversity in fertility (Shkolnikov et.al. 2004; including Austria: Spielauer 2005 ${ }^{1}$ ) and the highest rate of two-child families. (Russia ranked on the $4^{\text {th }}$ place in this comparison.) After the political and economic transition, period fertility dropped rapidly to lowest low levels, in Bulgaria nearing a TFR of 1 in 1997. Russia reached its lowest level (1.16) in 1999. The fertility drop results from changes in various demographic behaviors. In this paper, we aim at quantifying the individual effects of the observed changes in first and second birth

\footnotetext{
${ }^{1}$ The compared countries are: West Germany, Finland, USA, Ireland, Austria, Netherlands, England and Wales, Sweden, Italy, Romania, France, Denmark, Spain, Norway, Slovakia, Hungary, Greece, Russia, Slovenia, Czech Republic, Bulgaria. (Ordered by the concentration of reproduction measured by the Gini coefficient of the distribution of children to women of the 1960 birth cohort)
} 
risks in different life course situations as well as the impact of changes in union formation and dissolution risks on the overall first and second birth outcome. The study is based on six hazard regression models estimated from GGS data. While these processes are usually analyzed separately, we synthesize the corresponding models by means of microsimulation in order to assess the effect of changes of single parameters on overall fertility. For example, from the study of single processes we know that union dissolution risks increased by $58 \%$ in Russia, that union formation risks decreased by $44 \%$ in Bulgaria, and that in both countries first birth risks decreased by $50 \%$ in the first three years of first partnership. While these are interesting analytical results, they do not allow drawing an immediate conclusion on the individual impact of these changes on overall fertility. For such study, we have to examine the processes simultaneously. This is done using microsimulation.

The paper is organized as follows. We first start from a brief discussion of the data and the modeling strategy used. The following three sections address the key behaviors under study: fertility, union formation, and union dissolution. Each of the sections is divided into a general introduction on the key characteristics and changes of said behaviors, and the presentation of corresponding event-history models. We then introduce the microsimulation approach used and study the impact of individual processes on fertility. We complement the results by an investigation of birth by union order and the impact of union dissolution on fertility. The main findings are then summarized under the three central headings of fertility, union formation, and union dissolution.

\section{Data and modeling strategy}

Our study is based on Generations and Gender Survey (GGS) data collected from October to December 2004 in Bulgaria and from June to August 2004 in Russia. We only included women born in or after 1950 who are of Bulgarian and Russian ethnicity, respectively. We estimated the intensities of six events by means of piecewise constant hazard regression models. The events are first and second births, first and second union formations, and first and second union dissolutions. The sample size for the study of first births and first union formations is $n=4265$ for Bulgaria and $n=3695$ for Russia. The sample sizes and proportions of women who report to have experienced the event under study are displayed in Table 1. All processes are censored at age 40 and at second birth. We exclude all women from the sample, who reported a birth or first union before their $15^{\text {th }}$ birthday. 


\begin{tabular}{|l|r|r|r|r|}
\cline { 2 - 5 } \multicolumn{1}{c|}{} & \multicolumn{2}{c|}{ Bulgaria } & \multicolumn{2}{c|}{ Russia } \\
\cline { 2 - 5 } \multicolumn{1}{c|}{} & \multicolumn{1}{c|}{$\mathrm{n}$} & event & \multicolumn{1}{c|}{ n } & event \\
\hline First births & 4265 & $70 \%$ & 3695 & $80 \%$ \\
\hline Second births & 2969 & $56 \%$ & 2951 & $52 \%$ \\
\hline First union formation & 4265 & $74 \%$ & 3695 & $85 \%$ \\
\hline First union dissolution & 3144 & $9 \%$ & 3124 & $29 \%$ \\
\hline Second union formation & 297 & $42 \%$ & 905 & $55 \%$ \\
\hline Second union dissolution & 124 & $14 \%$ & 501 & $29 \%$ \\
\hline
\end{tabular}

\section{Table 1: Sample sizes and proportion of occurrence of events in the sample ${ }^{2}$}

We limit our analysis to first and second births due to the very small number of higher order births: the first two births account for $97 \%$ of all births reported in the Bulgarian population under study; Russia has a smaller number of $93 \%$. In the Bulgarian case, all first and second births occurred before a third partnership; for Russia this holds true for all but 19 cases, thus justifying our decision to model the first two partnerships only.

All models but second union dissolution (due to the small sample size) include a control variable for calendar period. We distinguish four periods, namely the "socialist period" (before 1989), and the periods 1989-1993, 1994-1998, and 1999+. All hazard regression models are then synthesized into a continuous time cohort microsimulation model. By running various scenarios, we then explore the individual contribution of the various processes to the overall fertility decline observed in the two countries.

\section{Fertility}

\subsection{The general characteristics of fertility and fertility change in Bulgarian and Russia}

During the first decade of post-communist Bulgaria and Russia, the two countries - as most countries of the socialist bloc - experienced a reduction in fertility that was steeper in relative terms than in Western Europe during any period of comparable length (UNECE 2000). Taking 1989 as reference year, the Total Fertility Rate (TFR) dropped by almost 43\% in the two countries, reaching its lowest level in 1987 in Bulgaria (1.09) and in 1999 in Russia $(1,16)$. Meanwhile, the TFR slightly increased to 1.29 in Bulgaria and to 1.34 in Russia (2004).

The stable fertility pattern before the political collapse of communism is well reflected in the age-specific fertility rates displayed for selected years in Figure 1. Both countries are characterized by a very early start to and end of the reproductive career of women (Philipov, 2001a), i.e. a high concentration of fertility to the age range 20-24. The sharp drop in fertility initially affected all age groups. As highlighted by Cornia and Paniccia (1995), in Russia it is very pronounced also for the age groups 30+; this in contrast to

\footnotetext{
${ }^{2}$ Note, that processes are censured at second birth.
} 
Bulgaria, where fertility at very young ages (15-19) decreased more rapidly. The recent (moderate) rise in period fertility results entirely from increasing fertility rates at ages $25+$. This is reflected in a rising mean age at birth. While the increase in the mean age at first birth is still moderate in Russia (Sobotka 2002) - from around 23 in the 1980s to 24 in 2004 - it is steeper in Bulgaria, where, starting from an initially lower age (22 years), it reached 24.4 in 2003.

\section{Russia}

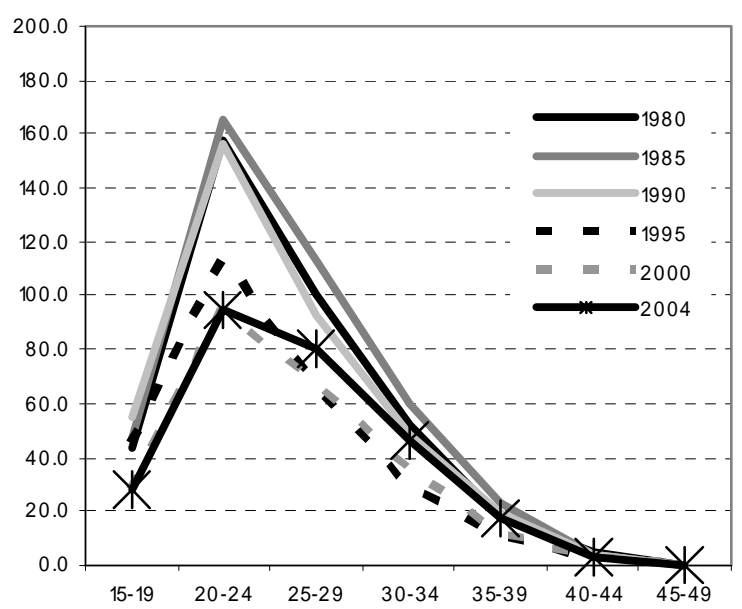

Bulgaria

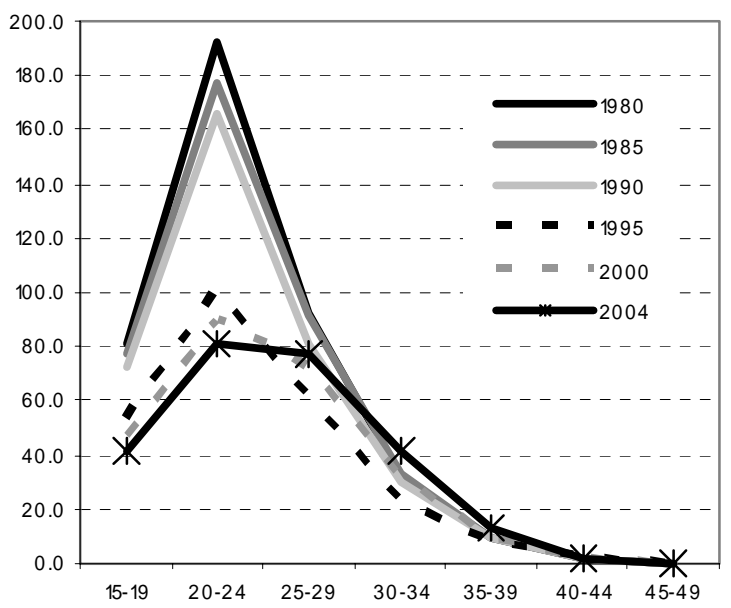

Source: GGP Contextual Database (2005)

Figure 1: Age specific fertility rates in Russia and Bulgaria

\subsection{The model for firsts births}

When modeling births, we generally refer to the time of conception (assumed to be nine months prior to the reported birth). This allows us to explicitly distinguish the period of pregnancy in models for union formation and dissolution. This is important as in Russia as well as in Bulgaria $20 \%$ of first conceptions occur before first union formation, followed by union formation within pregnancy.

First births are modeled by an age baseline hazard and an interaction of union status and calendar period. Concerning union status, we distinguish the categories "not in union", "first union <3 years", "first union > 3years", and "second union". Estimation results (Table 2) reveal almost identical patterns for Bulgaria and Russia, both concerning the baseline hazard and the interaction term. Most notable is the sharp reduction (by 50\%) in first birth risks in the first three years of first union and the equally strong decrease in first birth risk in second unions, whereas no change can be observed after three years into first partnership (Figure 2). This indicates both a quantum change in fertility and postponement. 


\begin{tabular}{|l|l|c|}
\cline { 2 - 3 } \multicolumn{1}{c|}{} & Bulgaria & Russia \\
\hline $15-17.5$ & $0.29 * * *$ & $0.21 * * *$ \\
$20-22.5$ & $0.76^{* * *}$ & $0.76 * * *$ \\
$22.5-25$ & $0.85 * * *$ & $0.83 * * *$ \\
$25-27.5$ & $0.82 * * *$ & $0.65 * * *$ \\
$27.5-30$ & $0.67 * * *$ & $0.54 * * *$ \\
$30-32.5$ & $0.51 * * *$ & $0.58 * * *$ \\
$32.5-35$ & $0.49 * * *$ & $0.49 * * *$ \\
$35-37.5$ & $0.26 * * *$ & $0.32 * * *$ \\
$37.5-40$ & $0.26 * * *$ & $0.31 * * *$ \\
\hline
\end{tabular}

\begin{tabular}{|c|c|c|c|c|c|c|c|c|}
\hline & \multicolumn{2}{|c|}{$<1998$} & \multicolumn{2}{|c|}{ 1989-1993 } & \multicolumn{2}{|c|}{ 1994-1998 } & \multicolumn{2}{|c|}{$1999+$} \\
\hline & Bulgaria & Russia & Bulgaria & Russia & Bulgaria & Russia & Bulgaria & Russia \\
\hline Not in union & $0.06 * * *$ & 0.09 *** & $0.07 * * *$ & $0.11 * * *$ & $0.05 * * *$ & $0.07 * * *$ & $0.03 * * *$ & $0.07 * * *$ \\
\hline First union < 3 years & 1 & 1 & 0.94 & 1.07 & $0.74 * * *$ & $0.60 * * *$ & $0.49 * * *$ & $0.51 * * *$ \\
\hline First union $>3$ years & $0.25 * * *$ & $0.28 * * *$ & $0.29 * * *$ & $0.29 * * *$ & $0.23 * * *$ & $0.32 * * *$ & $0.27 * * *$ & $0.27 * * *$ \\
\hline Second Union & 0.80 & $0.53 * * *$ & $0.21 * * *$ & $0.17 * * *$ & $0.40 * *$ & $0.31 * * *$ & $0.23 * * *$ & $0.27 * * *$ \\
\hline
\end{tabular}

Table 2: Parameter estimates for first births

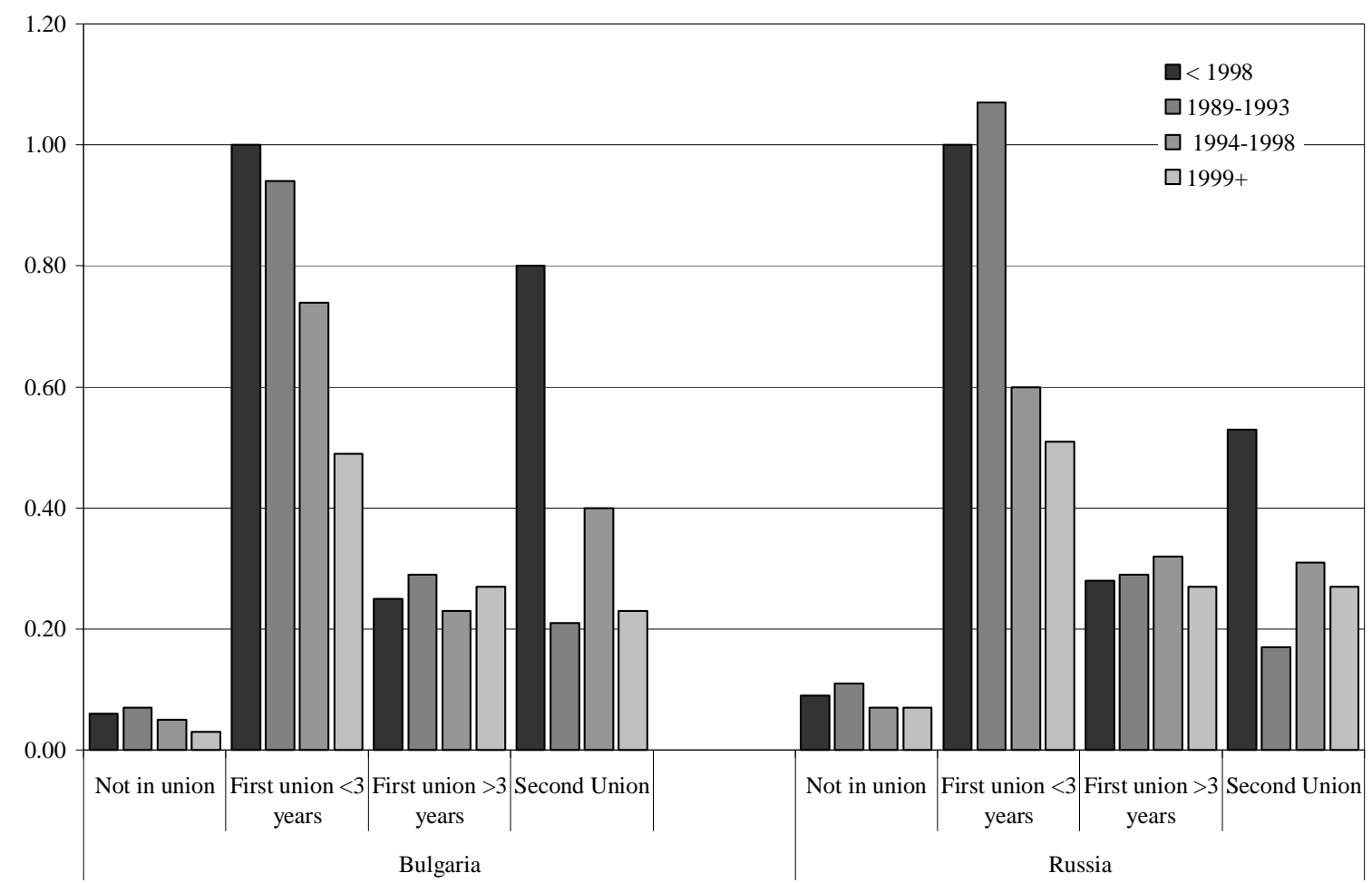

Figure 2: Interaction of calendar period and union status - first births

\subsection{The model for second births}

Comparing the baseline hazard of second conceptions - i.e. the time since first birth and the age profile of second birth risks between Russia and Bulgaria, we find an influence of these time-varying covariates that is much weaker in Russia than it is in Bulgaria. This is consistent with the longer birth intervals observed in Russia. In Bulgaria, by contrast, second conceptions occur sooner (and intensities decrease faster 
with age). Besides these differences, our analysis reveals almost identical patterns for the two countries concerning the sharp decline $(60 \%)$ in second birth risks in all union states and phases.

Second birth risks are two to three times higher in second unions compared to first unions, indicating a strong new partner effect. When the first birth occurred within a second union, this effect disappears, as expected; accordingly, second birth risks are higher when the first child was born out of union. Note that we count first conceptions followed by union formation within pregnancy as a birth within union when classifying the union status at first birth.

\begin{tabular}{|l|l|l|}
\cline { 2 - 3 } \multicolumn{1}{c|}{} & Bulgaria & Russia \\
\hline <0.5 years after first birth & $0.07 * * *$ & $0.07 * * *$ \\
0.5-1 years after first birth & $0.15 * * *$ & $0.13 * * *$ \\
1-2 years after first birth & $0.20 * * *$ & $0.12 * * *$ \\
2-4 years after first birth & $0.23 * * *$ & $0.16^{* * *}$ \\
4-6 years after first birth & $0.24 * * *$ & $0.18^{* * *}$ \\
6-8 years after first birth & $0.15 * * *$ & $0.13 * * *$ \\
8-10 years after first birth & $0.11 * * *$ & $0.12 * * *$ \\
10-12 years after first birth & $0.07 * * *$ & $0.13 * * *$ \\
12-17 years after first birth & $0.04 * * *$ & $0.08 * * *$ \\
17-22 years after first birth & $0.03 * * *$ & $0.02 * * *$ \\
22+ years after first birth & 0.00 & 0.00 \\
\hline First Birth not in Union & $1.34 * *$ & $1.47 * * *$ \\
First Birth in first union & 1 & 1 \\
First Birth in Second Union & $0.41 * *$ & $0.51 * * *$ \\
\hline
\end{tabular}

\begin{tabular}{|l|l|l|}
\cline { 2 - 3 } \multicolumn{1}{c|}{} & Bulgaria & \multicolumn{1}{|c|}{ Russia } \\
\hline $15-17.5$ & $1.76 *$ & 0.39 \\
$17.5-20$ & $1.76 * * *$ & 1.02 \\
$20-22.5$ & $1.29 * * *$ & 0.93 \\
$22.5-25$ & 1 & 1 \\
$25-27.5$ & 0.92 & $0.87 *$ \\
$27.5-30$ & $0.78 * * *$ & 0.87 \\
$30-32.5$ & $0.62 * * *$ & $0.71 * * *$ \\
$32.5-35$ & $0.48 * * *$ & $0.61 * * *$ \\
$35-37.5$ & $0.37 * * *$ & $0.37 * * *$ \\
$37.5-40$ & $0.20 * * *$ & $0.24 * * *$ \\
\hline
\end{tabular}

\begin{tabular}{|l|l|l|l|l|l|l|l|l|}
\cline { 2 - 8 } \multicolumn{1}{c|}{} & \multicolumn{2}{c|}{$<1998$} & \multicolumn{2}{c|}{$1989-1993$} & \multicolumn{2}{c|}{$1994-1998$} & \multicolumn{1}{c|}{$1999+$} \\
\cline { 2 - 9 } \multicolumn{1}{c|}{} & Bulgaria & Russia & Bulgaria & \multicolumn{1}{c|}{ Russia } & Bulgaria & \multicolumn{1}{c|}{ Russia } & \multicolumn{1}{c|}{ Bulgaria } & Russia \\
\hline Not in union & $0.29 * * *$ & $0.24 * * *$ & $0.19 * * *$ & $0.22 * * *$ & $0.09 * * *$ & $0.15 * * *$ & $0.12 * * *$ & $0.10 * * *$ \\
First union <3 years & 1 & 1 & $0.78 * *$ & 0.81 & $0.44 * * *$ & $0.47 * * *$ & $0.32 * * *$ & $0.27 * * *$ \\
First union >3 years & 0.92 & 1.02 & $0.64 * * *$ & $0.62 * * *$ & $0.44 * * *$ & $0.36 * * *$ & $0.45 * * *$ & $0.42 * * *$ \\
Second Union & $3.48 * * *$ & $2.49 * * *$ & 1.64 & $1.95 * * *$ & 1.58 & 1.29 & 1.20 \\
\hline
\end{tabular}

Table 3: Parameter estimates for second births 


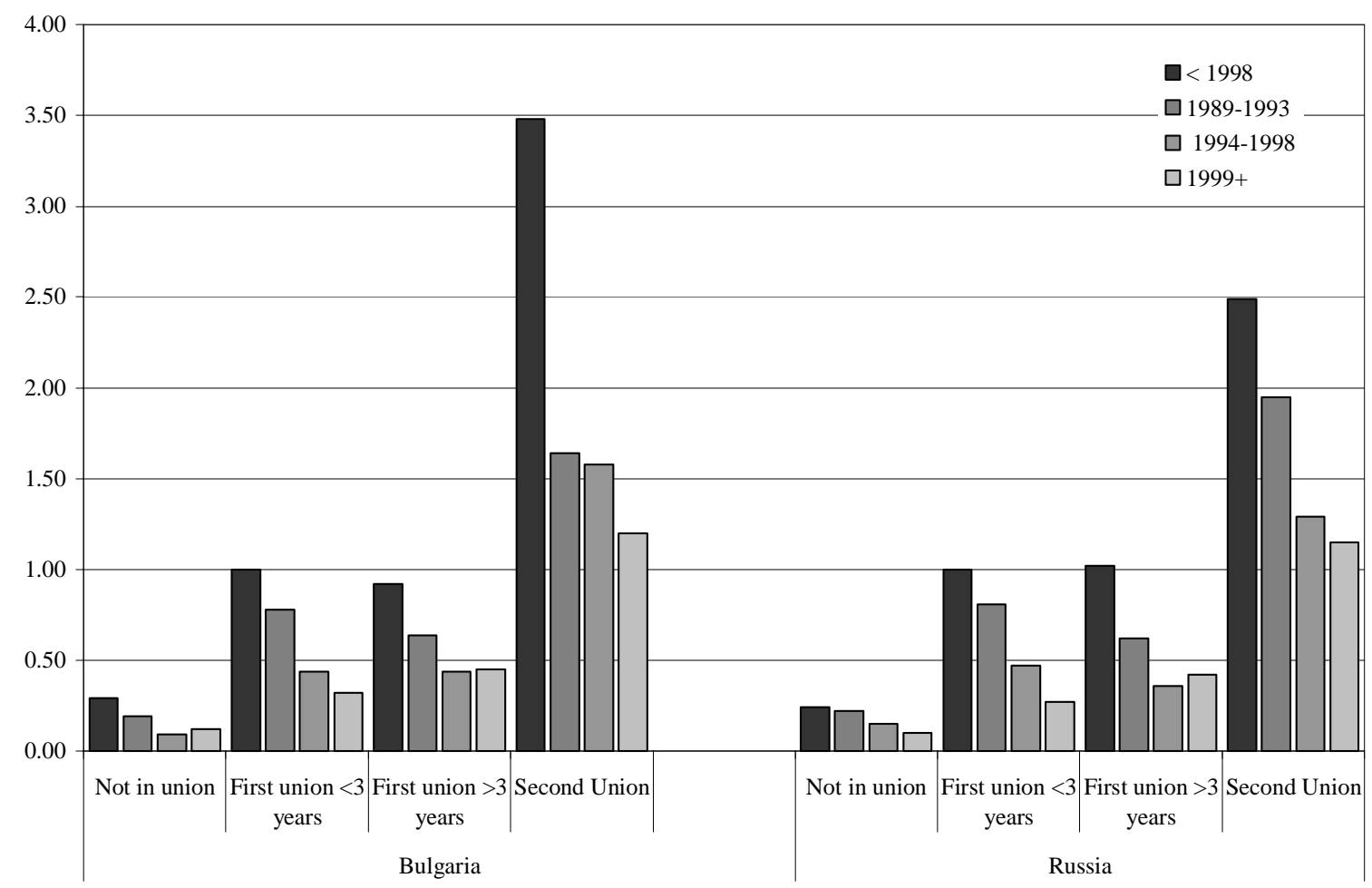

Figure 3: Interaction of calendar period and union status - second births

\section{Union formation}

\subsection{General characteristics of union formation in Bulgaria and Russia}

Very early age and the universality of marriage constitute the key characteristics of union formation patterns in socialist Bulgaria and Russia (Koytcheva 2006; Scherbov and Vianen, 2004; Avdeev and Monnier, 2000; Philipov, 2002; Sobotka at. al., 2003). The mean age of women at first marriage was below 22 years in both countries. The Total Female First Marriage Rate (TFFMR) neared 1 in both societies during the 1980s. The universality of marriage is also reflected in cohort data. Over $95 \%$ of the women born in the early 1950s have ever entered marriage before age 50 in Russia; for Bulgaria this proportion is $98 \%$ even. Early marriage (and parenthood) was supported by a comprehensive range of 'stimulating' social welfare programs (Lokshin at. al., 2000). The strong timing norms for early marriage are best reflected by a "bachelor tax" collected in Bulgaria from singles aged 21+ and childless couples after two years of marriage. A comparable "tax on childlessness" also existed in Russia and was collected from childless people aged $18+$ with an average rate of $6 \%$ of earnings. Privileged access to housing was another powerful "marriage incentive" in centrally planned economies. Bulgaria had a system of state loans geared to enable people to acquire accommodation. Marriage was a requirement in order to be eligible for the loan. $20 \%$ of the loan was deducted at the birth of a second child and an additional $30 \%$ by a third child. 
In the 1990s, marriage rates decreased rapidly, reaching a level below 0.5 in Bulgaria in 2002. The most recent data on Russia are available only for 1996; then the TFFMR stood at 0.6. Crude female first marriage rates decreased especially for the age groups below 25 , indicating marriage postponement. This is reflected in an increasing mean age at first marriage, reaching 25.2 in Bulgaria in 2003. In Russia, the increase is much weaker: the mean age of first marriage was 23.3 in 2004.

Alongside changing marriage behavior, non-marital cohabitation became a widespread new phenomenon. No official statistics are available for Russia until 1994; at this point in time, micro-census respondents were asked whether or not their marriage had been officially registered $^{3}$. The answers provided show that $4 \%$ of all women aged $16+$ and $7 \%$ of women living in partnership stated to live within the context of "unregistered marriage". For women below age 20, the proportion was 14\%. In Bulgaria of 2001, $13.1 \%$ of the population at reproductive age lived in non-marital unions ${ }^{4}$.

The fast spread of cohabitation over time is reflected in the rapid increase in the proportion of non-marital birth, climbing in Russia from 13\% in 1988 to $29.5 \%$ in 2002. As the recognition rate by both parents grew, too, the rise in non-marital births indicates a rise of "marriages not registered" (Zakharov, 2001). In Bulgaria of the 1980s, only around $10 \%$ of births were non-marital. Since 2004, however, non-marital births have been accounting for more than $50 \%$ of total births. This development resulted in a mean age of first birth below the mean age of first marriage.

Our analysis below does not distinguish between married and unmarried cohabitation. As noted above, we exclude ethnical minorities from our analysis. Suffice it to mention Bulgarian Roma as an example of an ethnic group following a very particular family formation model that does not consider formal registration as a prerequisite to being regarded as constituting a marriage within the ethnic group. (Ethnical differences in union formation are discussed e.g. in Pamporov 2003, Sougareva 1995, and Koytcheva 2005).

\subsection{The model of first union formation}

A comparison of the first union formation process between Bulgaria and Russia reveals three key features: (1) almost identical age baseline hazards, (2) a relatively close connection between first birth and union formation in Bulgaria, and (3) a sharp (44\%) decline in first union formation risks between 1989 and 1999 in Bulgaria, a trend that has not been noted for Russia. As stated earlier, around $20 \%$ of first conceptions in the two

\footnotetext{
${ }^{3}$ Resulting in the term "not registered marriages" in Russia, considered corresponding to cohabitation (Andreev and Monnier, 2000)

${ }^{4}$ Fertility and Reproductive Behavior Survey conducted in parallel to census in 2001, women aged 15-49, men aged 15-59.
} 
countries occur before first union formation and are followed by union formation within pregnancy. Relative first union formation risks are accordingly high during pregnancy. They also remain significantly higher (than before pregnancy) in the first year after birth and decrease rapidly afterwards in Bulgaria. The decline over time is less pronounced in Russia.

\begin{tabular}{|l|l|l|}
\cline { 2 - 3 } \multicolumn{1}{c|}{} & Bulgaria & Russia \\
\hline $15-17.5$ & $0.03 * * *$ & $0.03 * * *$ \\
$20-22.5$ & $0.13 * * *$ & $0.13 * * *$ \\
$22.5-25$ & $0.17 * * *$ & $0.19 * * *$ \\
$25-27.5$ & $0.17 * * *$ & $0.17 * * *$ \\
$27.5-30$ & $0.15 * * *$ & $0.12 * * *$ \\
$30-32.5$ & $0.11 * * *$ & $0.11 * * *$ \\
$32.5-35$ & $0.08 * * *$ & $0.08 * * *$ \\
$35-37.5$ & $0.03 * * *$ & $0.09 * * *$ \\
$37.5-40$ & $0.05 * * *$ & $0.04 * * *$ \\
\hline
\end{tabular}

\begin{tabular}{|l|l|l|}
\cline { 2 - 3 } \multicolumn{1}{c|}{} & Bulgaria & \multicolumn{1}{c|}{ Russia } \\
\hline Before first pregnancy & 1 & 1 \\
In first pregnancy & $18.38 * * *$ & $10.95 * * *$ \\
first year after birth & $1.71 * * *$ & 1.27 \\
year 2-3 after birth & $0.42 * * *$ & $0.48 * * *$ \\
year 4+ after birth & $\mathbf{0 . 2 9} * * *$ & $\mathbf{0 . 5 8} * * *$ \\
\hline Before 1989 & 1 & 1 \\
1989-1993 & 0.94 & $1.20 * * *$ \\
1994-1998 & $\mathbf{0 . 6 9} * * *$ & $\mathbf{1 . 0 2}$ \\
$1999+$ & $\mathbf{0 . 5 6} * * *$ & $\mathbf{1 . 0 2}$ \\
\hline
\end{tabular}

\section{Table 4: Parameter estimates for first union formation}

\subsection{The model for second union formation}

The higher first union dissolution risks observed for Russia are paralleled by baseline hazards of second union formation that are higher by around 30\% compared to Bulgaria. However, second union formation is linked more closely to pregnancy in Bulgaria, where relative risks are four times higher during pregnancy than before pregnancy. This effect is not noted for Russia.

\begin{tabular}{|l|l|l|}
\cline { 2 - 3 } \multicolumn{1}{c|}{} & Bulgaria & Russia \\
\hline <2 years after dissolution & $0.20 * * *$ & $0.26 * * *$ \\
2-6 years after dissolution & $0.14 * * *$ & $0.17 * * *$ \\
6-10 years after dissolution & $0.11 * * *$ & $0.14 * * *$ \\
10-15 years after dissolution & $0.03 * * *$ & $0.11 * * *$ \\
15+ years after dissolution & $0.05 * * *$ & $0.02 * * *$ \\
\hline Before first pregnancy & 1 & 1 \\
In first pregnancy & $3.99 * * *$ & 1.36 \\
Mother & $0.58 * * *$ & $0.66 * * *$ \\
\hline
\end{tabular}

\begin{tabular}{|l|l|l|}
\cline { 2 - 3 } \multicolumn{1}{c|}{} & Bulgaria & \multicolumn{1}{c|}{ Russia } \\
\hline Before 1989 & 1 & 1 \\
$1989-1993$ & 0.82 & 0.89 \\
$1994-1998$ & 0.85 & $0.75^{* *}$ \\
$1999+$ & 0.73 & 0.88 \\
\hline
\end{tabular}

Table 5: Parameter estimates for second union formation

\section{Union dissolution}

\subsection{General characteristics of union dissolution in Bulgaria and Russia}

Of all demographic behaviors studied in this paper, union stability is the only one where we find remarkable differences between Bulgaria and Russia as early as in socialist times. An elevated tendency to divorce and high remarriage rates are features particular to Russian nuptiality patterns (Sanjian, 1991). The Russian Total Divorce Rate stood at 0.4 
in 1990 and increased to 0.5 in $1995^{5}$. In Bulgaria, the trend in total divorce rates is relatively stable around 0.15 and 0.20 ; these figures are roughly two to three times lower than in Russia.

Our analysis below does not distinguish between divorce and the dissolution of cohabitations, frequently considered to be more unstable; this was confirmed for Russia by Muszynska (2006), who found that the dissolution risk is double as high for nonmarital unions. Due to the increase in cohabitation, we can expect a more pronounced increase in overall union dissolution risks than reflected in divorce rate trends.

\subsection{The model for first union dissolution}

Of all the processes under study, first union dissolution features the most notable difference between Bulgaria and Russia. Baseline hazards are two to four times higher in Russia; pregnancy and motherhood decrease the relative risks to a lesser degree in Russia than in Bulgaria, too. The third difference between the countries concerns calendar time effects: relative union dissolution risks increased sharply (by 58\%) between 1989 and 1999 in Russia, while this increase is far lower and statistically insignificant in Bulgaria.

\begin{tabular}{|l|l|l|}
\cline { 2 - 3 } \multicolumn{1}{c|}{} & Bulgaria & Russia \\
\hline 1st year of union & $0.01 * * *$ & $0.04 * * *$ \\
union duration 1-5 & $0.02 * * *$ & $0.06 * * *$ \\
union duration 5-9 & $0.02 * * *$ & $0.05 * * *$ \\
union duration 9-13 & $0.02 * * *$ & $0.04 * * *$ \\
union duration >13 & $0.01 * * *$ & $0.03 * * *$ \\
\hline before first pregnancy & 1 & 1 \\
during first pregnancy & $0.29 * * *$ & $0.63 * * *$ \\
first 3 years after birth & $0.53 * * *$ & $0.69 * * *$ \\
3-6 years after first birth & $0.61 * *$ & $0.76 * *$ \\
6-9 years after first birth & $0.60 * *$ & $0.68 * *$ \\
9+ years after first birth; & 0.90 & $0.70 *$ \\
\hline
\end{tabular}

\begin{tabular}{|l|l|l|}
\cline { 2 - 3 } \multicolumn{1}{c|}{} & Bulgaria & Russia \\
\hline Before 1989 & 1 & 1 \\
$1989-1993$ & 1.08 & 1.07 \\
$1994-1998$ & $1.48^{* *}$ & $1.36^{* * *}$ \\
$1999+$ & 1.26 & $1.58^{* * *}$ \\
\hline
\end{tabular}

\section{Table 6: Parameter estimates for first union dissolution}

\subsection{The model for second union dissolution}

Due to the small number of second union dissolutions in the sample - (17 in Bulgaria, 58 in Russia, censuring at second birth and at age 40) we only estimate duration baseline hazards for this event. In Russia, the risk of first union dissolution is much higher at least for the first eight years in second union.

\footnotetext{
${ }^{5}$ Since 1997 data on divorces by duration of marriage are not collected by Goskomstat/Rosstat, and therefore it is impossible to calculate duration-specific rates and total divorce rate.
} 


\begin{tabular}{|l|c|c|}
\cline { 2 - 3 } \multicolumn{1}{c|}{} & Bulgaria & Russia \\
\hline 3-9 years union duration & $0.04 * * *$ & $0.08 * * *$ \\
9+ years union duration & $0.01 * * *$ & $0.07 * * *$ \\
\hline
\end{tabular}

Table 7: Parameter estimates for second union dissolution

\section{Microsimulation analysis}

In order to study the individual contribution of the period effects estimated for the various processes to the overall decline in first and second births we compare synthetic cohorts generated by means of microsimulation. The model was coded in Modgen, a generic microsimulation language developed by Statistics Canada (Reference); the programming code is documented in Spielauer (2006). We simulated 26 scenarios per country, with a cohort size of 100,000 women each (which is sufficiently high to make Monte Carlo variability negligible). We distinguish two main scenarios: the baseline scenario of a "Socialist Cohort", i.e. a cohort of women who have lived in a pre-1989 world for the whole of their life, and a "Market Cohort", which is a cohort for which the parameters estimated for the period 1999+ apply over the whole life course. A comparison of the two main scenarios indicates an overall fertility decline of $36.8 \%$ in Bulgaria and of $25.5 \%$ in Russia. The decline is especially pronounced for second births, it dropped by almost $57 \%$ in Bulgaria and by slightly over $50 \%$ in Russia. For both countries, the share of women with a completed parity of (at least) two children fell from over $2 / 3$ to less than $1 / 3$. The key indicators of the two cohorts are displayed in Table 8 . The parity progression rates resulting from the simulation of the "socialist cohort" come very close to the observed values for the female cohort of 1960, as published e.g. in Shkolnikov et. al. (2006). We find a small difference in childlessness (which is higher in the simulated cohort) and a one-year-difference in the mean age at first birth in Bulgaria (also higher in the simulated cohort). Both differences can be explained by the exclusion of ethnic minorities; especially the Bulgarian Roma are known for their very low level of childlessness and very young age at first birth (Philipov 2001b).

\begin{tabular}{|l|r|r|r|r|}
\cline { 2 - 5 } \multicolumn{1}{c|}{} & \multicolumn{2}{c|}{ BULGARIA } & \multicolumn{2}{c|}{ RUSSIA } \\
\cline { 2 - 5 } \multicolumn{1}{c|}{} & "Socialist Cohort" & "Market Cohort" & "Socialist Cohort" & "Market Cohort" \\
\hline Average age 1st birth & 22.13 & 24.22 & 22.02 & 23.06 \\
Average age 2nd birth & 25.58 & 27.58 & 26.75 & 28.28 \\
\hline Percent childless & $7.3 \%$ & $27.5 \%$ & $6.2 \%$ & $13.8 \%$ \\
Percent one child & $23.8 \%$ & $42.8 \%$ & $27.6 \%$ & $53.1 \%$ \\
Percent two children & $68.9 \%$ & $29.7 \%$ & $66.3 \%$ & $33.1 \%$ \\
\hline CFR & 1.62 & 1.02 & 1.60 & 1.19 \\
\hline PP1 & 0.93 & 0.72 & 0.94 & 0.86 \\
PP2 & 0.74 & 0.41 & 0.71 & 0.38 \\
\hline Change 1st births & & $-21.8 \%$ & & $-8.2 \%$ \\
Change 2nd births & & $-56.9 \%$ & & $-50.1 \%$ \\
Change 1st+2nd births & & $-36.8 \%$ & & $-25.5 \%$ \\
\hline
\end{tabular}

Table 8: Simulated fertility indicators for a "Socialist" and a "Market" cohort 


\subsection{Impact of individual processes on fertility decline}

In order to identify the individual contribution of the various processes to the overall fertility change, we follow two approaches. In the first, we start from the baseline scenario of a "Socialist Cohort" and change only one set of parameters each to the "Market Cohort" values, thereby distinguishing 12 scenarios. We then calculate the percentage of births lost by each single change compared to the baseline scenario. In the second approach, we start from the "Market Cohort" and investigate, which percentage of "lost births" would be recovered if the single sets of parameters distinguished would move back to "Socialist Cohort" values.

Figure 4 presents the percentage of first, second, and total births lost when changing the single sets of parameters. As can be expected from the intensity regression models above, one of the striking differences between the two countries is caused by the decrease of first union formation risks observed in Bulgaria. When changing only first union formation risks to the "Market Cohort" values, $8,4 \%$ of first births, $14,5 \%$ of second births, and $11 \%$ of total births are lost in Bulgaria compared to the "Socialist Cohort". Another difference between the two countries concerns the magnitude of births lost due to changes in first and second birth parameters. The modifications of first birth parameters have a larger effect in Bulgaria; the alteration of second birth parameters causes a higher fertility decrease in Russia. Of all changes in single parameter sets, that in second birth risks within first unions has the highest effect on fertility. The magnitude in change is almost identical for both countries: $32 \%$ of second and 13\% of all births are lost.

Another difference between Russia and Bulgaria concerns the much higher chances of union dissolution risks in Russia. An increase of almost $60 \%$ in the risk of first union dissolution results in a relatively small percentage of births lost: $1.1 \%$. Below, we will study the effect of union dissolution on fertility separately. 


\begin{tabular}{|c|c|c|c|c|c|c|}
\hline & \multicolumn{3}{|c|}{ BULGARIA } & \multicolumn{3}{|c|}{ RUSSIA } \\
\hline & & Change & Change & & Change & Change \\
\hline & $\begin{array}{l}\text { Change } \\
\text { 1st births }\end{array}$ & $\begin{array}{l}\text { 2nd } \\
\text { births }\end{array}$ & $\begin{array}{c}1 \mathrm{st}+2 \mathrm{nd} \\
\text { births }\end{array}$ & $\begin{array}{l}\text { Change } \\
\text { 1st births }\end{array}$ & $\begin{array}{c}\text { 2nd } \\
\text { births }\end{array}$ & $\begin{array}{c}\text { 1st+2nd } \\
\text { births }\end{array}$ \\
\hline S1: new first birth risks in first union & $-3.7 \%$ & $-7.2 \%$ & $-5.2 \%$ & $-3.4 \%$ & $-7.0 \%$ & $-4.9 \%$ \\
\hline S2: new first birth risks in second union & $-0.4 \%$ & $-0.3 \%$ & $-0.3 \%$ & $-0.6 \%$ & $-0.5 \%$ & $-0.6 \%$ \\
\hline S3: new first birth risks out of union & $-3.4 \%$ & $-5.2 \%$ & $-4.2 \%$ & $-1.4 \%$ & $-2.2 \%$ & $-1.7 \%$ \\
\hline S4: new first birth risks (S1-3 combined) & $-9.0 \%$ & $-14.3 \%$ & $-11.2 \%$ & $-7.0 \%$ & $-11.3 \%$ & $-8.8 \%$ \\
\hline S5: new second birth risks in first union & & $-31.4 \%$ & $-13.4 \%$ & & $-31.9 \%$ & $-13.2 \%$ \\
\hline S6: new second birth risks in second union & & $-1.2 \%$ & $-0.5 \%$ & & $-3.9 \%$ & $-1.6 \%$ \\
\hline S7: new second birth risks out of union & & $-1.8 \%$ & $-0.8 \%$ & & $-3.6 \%$ & $-1.5 \%$ \\
\hline S8: new second birth risks (S5-7 combined) & & $-35.3 \%$ & $-15.0 \%$ & & $-41.6 \%$ & $-17.2 \%$ \\
\hline S9: new first union formation risks & $-8.4 \%$ & $-14.5 \%$ & $-11.0 \%$ & $0.2 \%$ & $0.4 \%$ & $0.3 \%$ \\
\hline S10: new second union formation risks & $-0.1 \%$ & $-0.5 \%$ & $-0.3 \%$ & $-0.1 \%$ & $-0.6 \%$ & $-0.3 \%$ \\
\hline S11: new union formation risks (S9-10 combined) & $-8.5 \%$ & $-14.9 \%$ & $-11.2 \%$ & $0.1 \%$ & $-0.2 \%$ & $0.0 \%$ \\
\hline S12: new union dissolution risks & $0.0 \%$ & $-0.2 \%$ & $-0.1 \%$ & $-0.3 \%$ & $-2.1 \%$ & $-1.1 \%$ \\
\hline Sum of partial effects $(S 1+2+3+5+6+7+9+10+12)$ & $-16.0 \%$ & $-62.3 \%$ & $-35.8 \%$ & $-5.6 \%$ & $-51.3 \%$ & $-24.6 \%$ \\
\hline Total change (changes combined ="Market Cohort") & $-21.8 \%$ & $-56.9 \%$ & $-36.8 \%$ & $-8.2 \%$ & $-50.1 \%$ & $-25.5 \%$ \\
\hline
\end{tabular}

\section{Table 9: Simulation scenarios of fertility decline by change of single processes}

In Table 10 (see below), we present the proportion of the total difference in births between the "socialist" and "market cohort" which would be lost - and recovered - by changing only one set of parameters each. For instance, in Bulgaria the change of first union formation risks alone would cause $38.4 \%$ of the total loss in first births; when using the "market cohort" as baseline, by moving just the first union formation risks back to "socialist cohort" values, $56.1 \%$ of first births would be recovered. The differences between the proportion lost and the proportion recovered is due to the different baseline cohorts; this can be best demonstrated by comparing the effect of second birth risks in second unions: In Russia, $7.8 \%$ of total births lost would have been lost only by changing the relative second birth risks in second unions to "market cohort" values. The other way round, starting from the "market cohort", where second unions are much more frequent due to $58 \%$ higher first union dissolution risks, moving second birth risks in second unions back to "socialist cohort" values would recover $13.4 \%$ of lost births.

Second births stay the single most important process also concerning a recovery of fertility in Russia; in Bulgaria, "moving back" first birth, second birth, or union formation risks to "socialist cohort" values would lead to an almost equally large recovery of lost births. 


\begin{tabular}{|c|c|c|c|c|c|c|}
\hline \multirow{2}{*}{$\begin{array}{l}\text { Bulgaria } \\
\text { Parameters modified: }\end{array}$} & \multicolumn{2}{|c|}{ 1st Births } & \multicolumn{2}{|c|}{ 2nd Births } & \multicolumn{2}{|c|}{ 1st \& 2nd Births } \\
\hline & \begin{tabular}{|c|} 
Loss as \\
proportion of \\
total loss
\end{tabular} & $\begin{array}{c}\text { Proportion } \\
\text { of total loss } \\
\text { recoverd }\end{array}$ & \begin{tabular}{|c|} 
Loss as \\
proportion of \\
total loss \\
\end{tabular} & $\begin{array}{c}\text { Proportion } \\
\text { of total loss } \\
\text { recoverd }\end{array}$ & \begin{tabular}{|c|} 
Loss as \\
proportion of \\
total loss \\
\end{tabular} & $\begin{array}{c}\text { Proportion } \\
\text { of total loss } \\
\text { recoverd }\end{array}$ \\
\hline S1: first birth risks in first union & $16.8 \%$ & $23.0 \%$ & $12.7 \%$ & $8.6 \%$ & $14.1 \%$ & $13.5 \%$ \\
\hline S2: first birth risks in second union & $1.7 \%$ & $3.9 \%$ & $0.5 \%$ & $0.6 \%$ & $0.9 \%$ & $1.7 \%$ \\
\hline S3: first birth risks out of union & $15.7 \%$ & $41.7 \%$ & $9.1 \%$ & $10.4 \%$ & $11.4 \%$ & $21.0 \%$ \\
\hline S4: first birth risks (S1-3 combined) & $41.2 \%$ & $60.9 \%$ & $25.1 \%$ & $18.0 \%$ & $30.5 \%$ & $32.6 \%$ \\
\hline S5: second birth risks in first union & & & $55.2 \%$ & $39.1 \%$ & $36.4 \%$ & $25.8 \%$ \\
\hline S6: second birth risks in second union & & & $2.1 \%$ & $2.2 \%$ & $1.4 \%$ & $1.4 \%$ \\
\hline S7: second birth risks out of union & & & $3.2 \%$ & $4.8 \%$ & $2.1 \%$ & $3.2 \%$ \\
\hline S8: second birth risks (S5-7 combined) & & & $62.0 \%$ & $45.1 \%$ & $40.9 \%$ & $29.8 \%$ \\
\hline S9: first union formation risks & $38.4 \%$ & $56.1 \%$ & $25.4 \%$ & $19.7 \%$ & $29.9 \%$ & $32.0 \%$ \\
\hline S10: second union formation risks & $0.5 \%$ & $0.8 \%$ & $0.9 \%$ & $0.7 \%$ & $0.7 \%$ & $0.7 \%$ \\
\hline S11: union formation risks (S9-10 combined) & $38.8 \%$ & $57.2 \%$ & $26.1 \%$ & $20.5 \%$ & $30.4 \%$ & $33.0 \%$ \\
\hline S12: union dissolution risks & $0.2 \%$ & $1.4 \%$ & $0.4 \%$ & $0.6 \%$ & $0.3 \%$ & $0.9 \%$ \\
\hline
\end{tabular}

\begin{tabular}{|c|c|c|c|c|c|c|}
\hline \multirow[t]{2}{*}{ Russia } & \multicolumn{2}{|c|}{ 1st Births } & \multicolumn{2}{|c|}{ 2nd Births } & \multicolumn{2}{|c|}{ 1st \& 2nd Births } \\
\hline & \begin{tabular}{|c|} 
Loss as \\
proportion of \\
total loss \\
\end{tabular} & $\begin{array}{c}\text { Proportion } \\
\text { of total loss } \\
\text { recoverd }\end{array}$ & $\begin{array}{c}\text { Loss as } \\
\text { proportion of } \\
\text { total loss }\end{array}$ & $\begin{array}{c}\text { Proportion } \\
\text { of total loss } \\
\text { recoverd }\end{array}$ & $\begin{array}{c}\text { Loss as } \\
\text { proportion of } \\
\text { total loss } \\
\end{array}$ & $\begin{array}{c}\text { Proportion } \\
\text { of total loss } \\
\text { recoverd }\end{array}$ \\
\hline S1: first birth risks in first union & $41.8 \%$ & $62.5 \%$ & $14.0 \%$ & $10.4 \%$ & $19.2 \%$ & $20.2 \%$ \\
\hline S2: first birth risks in second union & $7.6 \%$ & $22.3 \%$ & $1.0 \%$ & $1.6 \%$ & $2.2 \%$ & $5.5 \%$ \\
\hline S3: first birth risks out of union & $16.8 \%$ & $33.0 \%$ & $4.3 \%$ & $4.2 \%$ & $6.6 \%$ & $9.6 \%$ \\
\hline S4: first birth risks (S1-3 combined) & $85.4 \%$ & $96.5 \%$ & $22.6 \%$ & $14.5 \%$ & $34.4 \%$ & $29.9 \%$ \\
\hline S5: second birth risks in first union & & & $63.7 \%$ & $52.5 \%$ & $51.8 \%$ & $42.7 \%$ \\
\hline S6: second birth risks in second union & & & $7.8 \%$ & $13.4 \%$ & $6.4 \%$ & $10.9 \%$ \\
\hline S7: second birth risks out of union & & & $7.2 \%$ & $10.0 \%$ & $5.8 \%$ & $8.1 \%$ \\
\hline S8: second birth risks (S5-7 combined) & & & $83.0 \%$ & $71.4 \%$ & $67.4 \%$ & $58.0 \%$ \\
\hline S9: first union formation risks & $-2.0 \%$ & $-2.5 \%$ & $-0.8 \%$ & $-0.6 \%$ & $-1.0 \%$ & $-1.0 \%$ \\
\hline S10: second union formation risks & $0.7 \%$ & $2.4 \%$ & $1.1 \%$ & $1.3 \%$ & $1.0 \%$ & $1.5 \%$ \\
\hline S11: union formation risks (S9-10 combined) & $-1.3 \%$ & $-0.2 \%$ & $0.3 \%$ & $0.7 \%$ & $0.0 \%$ & $0.5 \%$ \\
\hline S12: union dissolution risks & $4.1 \%$ & $15.4 \%$ & $4.1 \%$ & $2.7 \%$ & $4.1 \%$ & $5.1 \%$ \\
\hline
\end{tabular}

Table 10: Proportion of total fertility decline lost and recovered by change of single processes.

\subsection{Births and union order}

One of the key characteristics of recent demographic change in Russia is the sharp increase $(58 \%)$ of first union dissolution risks, already starting from a level three times higher than in Bulgaria. This development shows that second unions have become increasingly important in terms of fertility, especially for higher order births. In the Russian "Market Cohort", almost 1/4th of second births occur in second unions - a duplication compared to the "Socialist Cohort". In Bulgaria, by contrast, second unions are only of marginal importance, where they account for $3.5 \%$ of second births only. Table 11 below displays the proportions of first and second births by union status and order. 


\begin{tabular}{|c|c|c|c|c|c|c|}
\hline & \multicolumn{3}{|c|}{$\overline{\text { BULGARIA }}$} & \multicolumn{3}{|c|}{ RUSSIA } \\
\hline & $\begin{array}{l}\text { Birth in } \\
\text { first } \\
\text { union }\end{array}$ & $\begin{array}{l}\text { Birth in } \\
\text { second } \\
\text { union }\end{array}$ & $\begin{array}{l}\text { Birth not } \\
\text { in union }\end{array}$ & $\begin{array}{l}\text { Birth in } \\
\text { first } \\
\text { union }\end{array}$ & $\begin{array}{l}\text { Birth in } \\
\text { second } \\
\text { union }\end{array}$ & $\begin{array}{l}\text { Birth not } \\
\text { in union }\end{array}$ \\
\hline First birth "Socialist Cohort" & $89.1 \%$ & $1.9 \%$ & $9.0 \%$ & $77.6 \%$ & $5.7 \%$ & $16.6 \%$ \\
\hline First birth "Market Cohort" & $84.3 \%$ & $2.2 \%$ & $13.5 \%$ & $77.3 \%$ & $8.6 \%$ & $14.1 \%$ \\
\hline Second birth "Socialist Cohort" & $92.5 \%$ & $3.0 \%$ & $4.4 \%$ & $79.9 \%$ & $11.8 \%$ & $8.4 \%$ \\
\hline Second birth "Market Cohort" & $90.1 \%$ & $3.5 \%$ & $6.4 \%$ & $67.3 \%$ & $24.0 \%$ & $8.8 \%$ \\
\hline
\end{tabular}

\section{Table 11: First and second births by union status and order}

What is the effect of first union dissolution on final fertility? The event-history models for second births indicate a considerable new partner effect leading to a relative second birth risk in second unions that is three times higher than in first unions. However, we have to consider that the process of second union formation is time-intensive and that eventually a considerable proportion of women does not enter a new partnership.

The following graph (Figure 4) illustrates the effect of union disruption on second births for women who have given first birth within first union. We compared the probabilities of progressing on to a second birth after $\mathrm{n}$ conception free years (since first conception) between women with and without a union disruption in period n. For example: If a woman of the "socialist cohort" did not experience a second conception in the first five years after first conception, a union dissolution at this point in time does not influence the probability of having another child. After five years, a union dissolution increases the probability of having a second child. In the Russian "Market Cohort", the dissolution of a first union has almost no influence on second birth probabilities at any time. This explains why even an increase in first union dissolution hazards by $58 \%$ has almost no effect on the final birth outcome. The simulation results displayed in Figure 4 reveal the role of second union formation in fertility recovery after union disruption. In Russia, independent of the cohort, around 2/3rd of the studied women entered a new union after first union disruption. In Bulgaria, this proportion is considerably smaller, constituting around 50\% in the "Socialist Cohort" and 40\% in the "Market Cohort". Comparing the "Market Cohorts" of both countries, we find almost identical probability patterns for both countries, except that in Russia the fertility gap between women with and without a union disruption is closed due to the higher proportion of second partnerships: second birth probabilities are almost identical between Bulgarian and Russian women when decomposed by union status. 

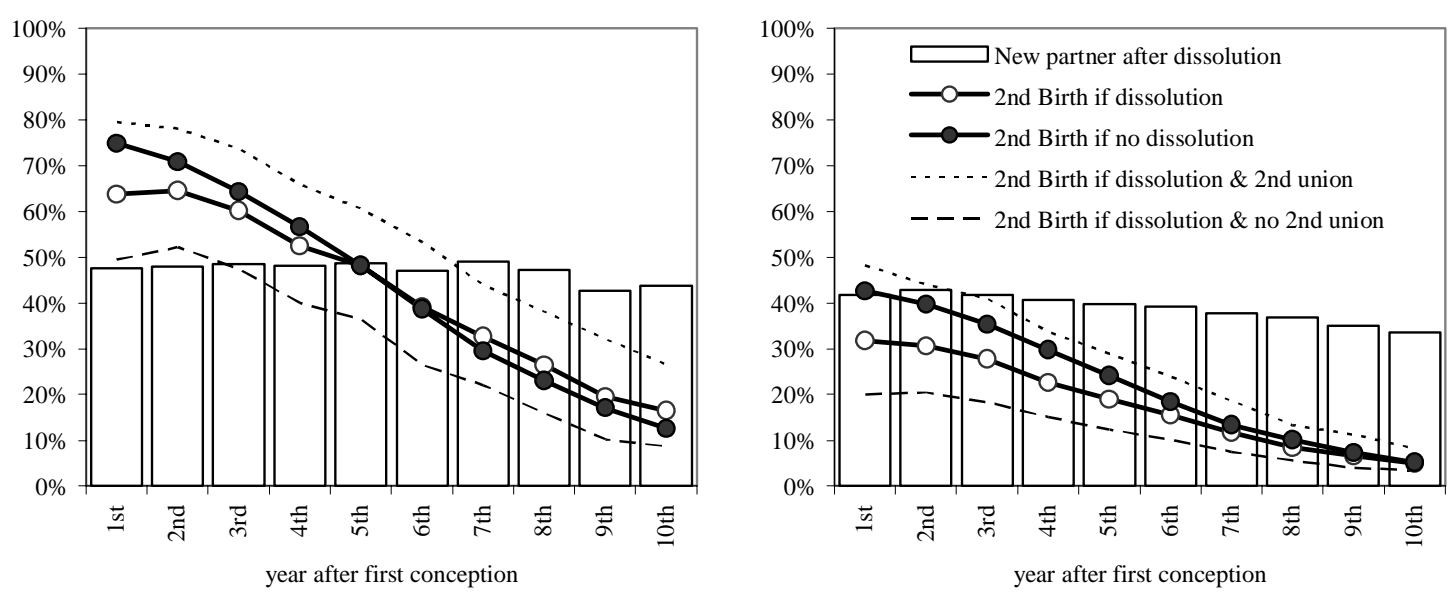

Russia "Socialist Cohort"

Russia "Market Cohort"
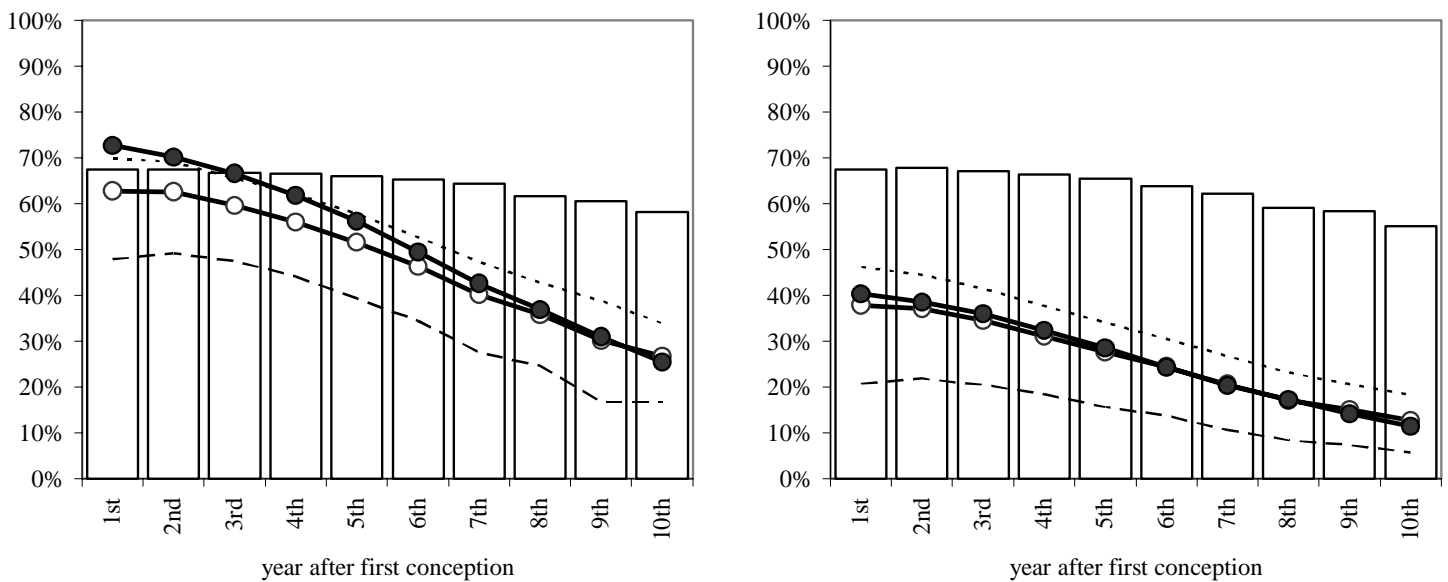

Figure 4: The influence of union dissolution on second birth probabilities

\section{Summary}

Comparing the simulated "socialist" and "market" cohort, first births dropped by $22 \%$ in Bulgaria and by $8 \%$ in Russia. In spite of this difference, the first birth models reveal almost identical patterns for both countries. This holds true both for the "socialist cohort", which represents the point of origin in the study of the fertility decline, and the changes in first birth risks since 1989. In both countries, conception risks decreased by $50 \%$ in the first three years of first unions and they remained constant thereafter. An equally strong fertility decline as in the first three years of first unions can be observed for second unions. The simulations reveal that a change in first birth risks alone would have led to $9 \%$ and $7 \%$ fewer first births in Bulgaria and Russia, respectively. In other words, in Russia the drop in first births can be attributed almost entirely to changes in first birth intensities, while the much higher decrease in first births in Bulgaria results from changes in other processes as well, predominantly the delay of union formation. If first birth intensities moved back to their initial "socialist cohort" values, $60 \%$ of lost first 
births would be recovered; in Russia, the recovery rate would be $97 \%$. As the drop in first births also decreases the number of women under risk for second births, the change of first birth intensities leads to a reduction in second births by $14 \%$ in Bulgaria and by $11 \%$ in Russia.

Concerning second births, the main difference between the two countries are the longer birth intervals in Russia. Since 1989, both countries experienced very similar changes, most importantly a decrease in second birth intensities by around $60 \%$. Second births decreased by $57 \%$ in Bulgaria and by $50 \%$ in Russia. The change in second birth intensities can be attributed in the main to the decline in second births in Russia: $42 \%$ of them would have been lost by changing only second birth intensities in the simulation. In Bulgaria, a change in second birth parameters leads to only $35 \%$ fewer second births, indicating the importance of other processes. In Bulgaria, starting from the market cohort, "moving back" second birth risks would recover $45 \%$ of the second births lost and $30 \%$ of the total lost births. As for first births, the recovery rate would be much higher in Russia, with $71 \%$ for second births and $58 \%$ for total births.

Concerning union formation, we found almost identical risk patterns in times of communism. We observed no changes in union formation in Russia, but a $44 \%$ drop in first union formation intensities in Bulgaria. A much higher percentage of women enter a new union after union dissolution in Russia. For instance, $70 \%$ of mothers of one child enter a new union after union dissolution compared to $40 \%$ in Bulgaria. If only union formation risks would have changed since 1989, this would have led to a reduction in first births by $9 \%$, by $15 \%$ in second births, and by $11 \%$ as to total births in Bulgaria; the effect is missing in Russia. If union formation risks are "changed back" to their original setting, Bulgaria would recover $33 \%$ of the total births lost We can conclude that the decline in union formation risks in Bulgaria is responsible for most of the inter-country difference in fertility decline.

Before 1989, union dissolution risks were around three times higher in Russia than they were in Bulgaria and then after further increased by $58 \%$ in Russia; in Bulgaria the increase was much less pronounced and not statistically significant. High union dissolution risks together with high second union formation intensities observed for Russia doubled the proportion of second conceptions in second unions from $12 \%$ to $24 \%$. In Bulgaria, these proportions are 3\% and 3.5\% respectively. Surprisingly, the sharp increase in union dissolution risks in Russia has almost no effect on second birth probabilities: the strong new partner effect almost compensates for the share of women staying single after union dissolution. 


\section{Acknowledgements}

We are thankful to Susann Backer for careful language editing of this contribution.

\section{References}

Avdeev, A, A. Monnier (2000) Marriage in Russia: a complex phenomenon poorly understood, Population: An English section, v.12, pp.7-49

Cornia, Giovanni A. and Renato Paniccia. 1995. "The Demographic Impact of Sudden Impoverishment: Eastern Europe During the 1989-94 Transition." Innocenti Occasional Papers, Economic Policy Series 49.

Koytcheva, E. (2005). Contemporary union formation in Bulgaria: the emergence of cohabitation XXV. International Population Conference, IUSSP. Tours, France, (presentation).

Koytcheva, Elena. 2006. "Social-Demographic Differences in Fertility and Family Formation in Bulgaria Before and After the Start of the Societal Transition." PhD Thesis, University of Rostock.

Lokshin, M., K. Harris, B. Popkin (2000) Single mothers in Russia: household strategies for coping with poverty, World development, 28(12) pp. 2183-98

Muszynska, M. (2006) Woman's employment and union disruption in a changing socioeconomic context: the case of Russia, Rostock, MPIDR Working Paper WP-2006-027.

National Statistical Institute. 2005. Statistical Yearbook. Sofia

Pamporov, A. (2003) The Second Demographic Transition is Impossible: Family Patterns of Roma (Gypsies) in Bulgaria. Poster presented at the Euresco Conference 2003 - The Second Demographic Transition in Europe, Spa, Belgium, 19-24, June, 2003

Philipov, Dimiter and Hans-Peter Kohler. 2001. "Tempo Effects in the Fertility Decline in Eastern Europe: Evidence From Bulgaria, the Czech Republic, Hungary, Poland and Russia." European Journal of Population 17(1):37-60.

Philipov, Dimiter. 2001. "The Demographic Situation of the Largest Ethnic/Minority Groups in Bulgaria." Paper Prepared for the Conference on The Demography of the Balkans in the Second Half of the 20th Century.

Philipov, Dimiter. 2002. "Fertility in Times of Discontinuous Societal Change: The Case of Central and Eastern Europe." MPIDR Working Paper WP 2002-024.

Sanjian, A. (1991) Social problems, political issues: marriage and divorce in USSR, Soviet studies, 43(4), pp. 629-49

Scherbov, S., H. Vianen (2004) Marriage in Russia; A reconstruction Demographic research, 10(2), pp. 27-60 
Shkolnikov, V. M.; Andreev, E.M.; Houle, R.; Vaupel, J. W. (2004) To concentration of reproduction in cohorts of US and European women; Rostock, MPIDR Working Paper WP-2004-027.

Sobotka, T., K. Zeman, V. Kantorova (2003) Demographic shifts in the Czech republic after 1989: a second demographic transition view, European journal of population, 19(3), pp. $249-277$

Sobotka, Tomas. (2002). "Ten Years of Rapid Fertility Changes in the European PostCommunist Countries. Evidence and Interpretation." Population Research Center, Working Paper Series, 02-1.

Sougareva, M. (1995) Marriage and divorce rate in Bulgaria by ethnicity (based on data from the last Census), Nasselenie, 1-2, pp. 113-124

Spielauer, M. (2005). Concentration of reproduction in Austria: general trends and differentials by educational attainment and urban-rural setting. In: Lutz, W.; Feichtinger, G. (Eds.): Vienna yearbook of population research 2005. Vienna: Austrian Academy of Sciences Press, 171-195.

UNECE. 2000. "Fertility Decline in the Transition Economies, 1989-1998: Economic and Social Factors Revisited, Chapter 6." Economic Survey in Europe, Geneva: United Nations Economic Commission for Europe.

Zakharov, S., E. Ivanova (2001) Wnebrachnie deti (Children out of marriage) in: Population and society, 59, pp. 1-4, (in Russian) 